Ojo, O.A

Faculty of Education, University of Fort Hare, East

London Campus, South Africa.

Email:oojo@ufh.ac.za

Adu, E.O

Faculty of Education, University of Fort Hare, East

London Campus, South Africa.

Email: eadu@ufh.ac.za

DOI: $h$ ttp://dx.doi. org/10.18820/2519593X/pie. v35i2.5

ISSN 0258-2236

e-ISSN 2519-593X

Perspectives in Education

2017 35(2): 60-72

(c) UVIUFS

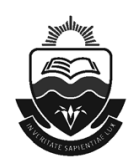

\section{Transformation of teaching quality in secondary school education: Teachers' conception}

\begin{abstract}
Teaching is a versatile and valued exercise that is geared towards bringing about achievement in students' learning. In view of the importance of teaching, there is need for it to be effective and of good quality. Education in secondary school within South Africa is seen as an imperative sub-sector in the educational system that aids the growth of the economic system through transformation. Although, there are various transformational systems to improve teaching quality in education, it is generally believed that there is no common agreement on what transformation systems entail in secondary school education in developing nations. This study investigates the perceptions of teachers in the transformation of teaching quality education in secondary schools. Eight teachers were selected from four secondary schools in the East London Education District in South Africa. The respondents varied in gender, age, years of teaching experience, academic qualifications and professional qualifications. The study used semi-structured interviews to gather data. A thematic approach was used for data analysis while trustworthiness was adopted for the validity of the instrument. The findings revealed that some of the teachers were aware of the need for transformation to improve the secondary school education system in South Africa. However, it was noticed that there was no adequate training and monitoring on the use of infrastructure. In addition, the findings further indicated that some teachers have a negative perception toward any additional role in transforming and improving the quality of teaching. Furthermore, the findings also indicated that transformation in teaching should be the responsibility of the government and head of schools. In light of this, the study recommended that policy makers should increase the budget on secondary school education as well as monitor the process of implementation to achieve the desired goal. Moreover, there should be regular effective training and workshops for teachers in secondary schools to remind them of their roles and responsibilities in teaching.
\end{abstract}

Keywords: Education, conception, interview, quality, secondary education, teachers, teaching, transformation

\section{Introduction}

Teaching connotes the activities that the teachers do to impact ideas and knowledge into the learners. To this effect, the teacher has the onerous task of arousing the interest of the pupil to participate actively in the teaching-learning process. In another vein, Olaitan and Agusiobo (2001) hold 
that teaching is a means to inculcate desirable changes in human abilities and behaviours. This indicates that the term teaching is meant to cause the learners to make certain desirable changes in their behavioural patterns, which involves classroom chatting between teacher and pupils within certain defined activities. Teaching then implies and involves not only a change in behaviours but also a means of sharing and communicating that usually result in the growth and development of a pupil in terms of knowledge, skills and attitude. Odor (2001) throws further light on the concept of teaching by submitting that teaching is the process of guiding, stimulating, motivating and evaluating the learner in an organised educational institution through a well-planned and selected educational programme of instruction towards the achievement of desired goals, including the all-round development of the learner. Here, the teacher is seen as a person of many parts: a guide, stimulator or motivator and evaluator, among others. Therefore, it is imperative to have effective and quality teaching in secondary school.

Education in secondary schools within South Africa and in other African countries is paramount to development. Moreover, it facilitates the growth of economic situation of any country. Vavrus (2009) states that the improvement on the quality of secondary school education is seen to be paramount in overall education. In this regard, it is required of an individual to perform excellently in any given task at any time. Despite this notable growth, research has shown that there is little or no agreement on the major characteristics of quality education, especially in the area of teaching and learning in secondary schools globally (Shahzad, 2007; Bedi \& Sharma, 2006) and across nations (Mosha, 2000; Hakielimu, 2007). Most studies have focused mainly on higher education but not secondary schools (Mosha, 2000; Bedi \& Sharma, 2006; Shahzad, 2007).

Secondary school education can be seen as a plan for an efficient and effective way of transformation in all sectors in all African state's development. The formal secondary education is the most crucial of all national investments because of its roles in the production of knowledge. Moreover, the secondary school system of education is regarded as a formal institution responsible for knowledge, skills and attitude development that helps individuals to fit into a society and have an ability to contribute meaningfully and productively to its development (Boaduo, 2005). Effectiveness in teaching is a dimensional way that depends on various resources working together in achieving the set goals. Fundamentally, it requires a look at results of the outcomes and an institution's accomplishments. It means questions about whether school graduates are well prepared, whether they have the knowledge and skills that they and society expect as a result of their studies (Chapman \& Austin, 2002: 209-210).

South African secondary schools have used traditional teaching methods for the past few decades to transfer knowledge to learners. Schools in South Africa, most importantly, the ones that are disadvantaged in terms of infrastructures, face numerous constraints ranging from the inability of parents to pay students' school fees to the neglect of schools on the part of the government. Many secondary schools in South Africa do not use ICT in teaching and learning and this has led to South Africa's ineffectiveness in the recent development and advancement in the educational sector.

The development of education in South Africa has experienced various stages of transformation in the last two decades (Isaacs, 2007). The National Qualification Framework for schools that was based on Outcomes-Based Education (OBE) happens to be central to this transformation (Isaacs, 2007). OBE considered the $21^{\text {st }}$ century as a period of dramatic 
change and development. In addition,, it highlights the other roles of teachers to be learning mediators, curriculum interpreters, leaders, managers and administrators, masters of his/her subject areas, scholars, facilitators of learning, subject experts, lifelong learners, learning designers, programme innovators and teaching material developers (National Curriculum Statement [NCS], 2003). Furthermore, those who designed the NCS consider the process of learning as important as the content; hence, one of its critical outcomes envisages learners "who will be able to use science and technology effectively and critically, showing responsibility towards the environment and the health of others" (DoE, 2013:8).

However, consistent studies of secondary school education in most African countries such as South Africa are highly needed due to the importance and the challenges facing the education system. In light of this, Sumra and Rajani (2006) reveal that most secondary school students finish their education without the necessary required skills for sustainability in life. This indicates that the main objective of having quality education in secondary school is neglected because of expansion (Hakielimu, 2007; Makombe et al., 2010).

In another study, it was gathered that the process of teaching in schools is bad due to a lack of motivation and inadequate training for the teachers to face the day-to-day challenges in the profession (Wedgwood, 2007; Komba \& Nkumbi, 2008; Ngimbudzi, 2009). Moreover, education in secondary schools has become ineffective due to the lack of fundamental skills and facilities required by teachers to function well (Benell \& Mukyanuzi, 2005). The act of teaching in secondary education in most cases is ineffective for the proper preparation of competent individuals (Bedi \& Sharma, 2006; Davidson, 2006). The students that graduate from secondary schools are seen as unprepared individuals that failed in demonstrating competencies required in work and life (Benson, 2005). Based on this, they become a burden in the society at large (Shahzad, 2007). Moreover, secondary school teachers are usually accused of giving limited attention to teaching conceptual knowledge instead of procedural; this indicates that most students engage in memorisation rather than understanding the formation or concept (Wedgwood, 2007).

\section{The quality of teaching as an agent of transformation in secondary school education}

The aims of African secondary education, according to Boaduo (2005:14), include:

1. "The major relevance of education is to ensure adequate provision for growth and to avoid any hampering influences

2. Also, adequate education is meant to provide cultural heritage necessary for an individual and for the development of his/her capacities maximally.

3. Furthermore, the role of education is to be broad and focus more on the relevance to the community rather than in relation to an individual will focus on training useful citizens".

A good teacher, according to Ololube (2005:17-31), can be best described through his/her knowledge of subject matter during the process of teaching. This in a way creates awareness and excitement in the form of the wake of a passing train. He explained further that a good teacher always endeavours to pull students along and not tie students down. The most attractive part of teaching according to his ideology is all about how teachers create a platform to love their students. Moreover, it is required of a teacher to have passion for one's field of study and for one's students rather than remaining as a scholar. Bigg (2003: 23) reveals that, 
"good teaching is making [the] majority of the students to make use of the higher cognitive level processes that is meant for more academic students".

According to Mosha (2000), quality is a high degree of goodness or excellence. In the same light, Lomas (2002) refers to quality as a degree of fitness to the customer's desire to ascertain the maximum level of satisfaction with effectiveness in the service offered (Manyanga, 2007). In view of this, quality means the extent to which the customers' satisfaction is met over the product or service received at any given time. Quality can be seen as a propelling force that drives the transformation of secondary school education to be about necessary terms of change (Lomas, 2002). In human perspectives, to change means a variation in structure or event in order to look more different, with some element of modification or adjustment.

Nevertheless, in the case of education, the learning of a child is not easily adjustable or modified since it is not an absolute or solid object. Rather, it takes a gradual developmental process that takes a qualitative change. For example, the increase in learning becomes a process of transformative change that enables a learner to move from one level of understanding to another. With this in mind, transformation is therefore a form of social change that includes behavioural, emotional, psychological and moral change (Eckel, Hill \& Green, 2002). The rate at which scholars are researching into the area of quality in education is becoming more interesting. There are several studies conducted on different areas relating to the definition of quality in education (Lomas, 2007; Parri, 2006; Manyanga, 2007). According to Lomas (2002), the quality in higher education is understood from four perspectives namely: fitness for purpose, value for money, transformation and excellence.

Internationally, research has shown that the teaching quality in education is imperative for the national development of any country, which advances the economic growth of the nation and at the same time increases the output of the affected teacher. It is clearly shown that attainment goes beyond merely the amount of schooling but the efficiency of teaching (Hanushek \& Woessman, 2007; Murnane et al., 2001). In African countries, it was noted that there was a great expansion to schooling in recent years. Nevertheless, there is record of low quality considering the international assessments and this has generated plenty of debate about whether these expansions of schooling have led to deteriorations in quality of education. The South African case requires relevant attention particularly because we have made great strides in providing access to schooling, but the quality in terms of teaching and general school performance cannot be overemphasised. Therefore, this study investigated the teachers' conception on the transformation of teaching quality in secondary school education.

\section{Research questions}

1. What conceptions do teachers have on the strategies of transformation in improving the teaching quality of secondary school education in South Africa?

2. What conceptions do teachers have on their role in transforming and improving teaching quality of secondary school education in South Africa?

\section{Research methodology}

Research methodology encompasses the study of procedures (methods) used in research to create new knowledge (Terre Blanche, Durrheim \& Panther, 2006). This section is an in depth report on the research design, sample and sampling techniques, research instruments and data analysis. 


\section{Research design}

According to Gelo, Braakmann and Benetka (2008: 272), "a research design is a plan of action or structure which links the philosophical foundations and the methodology assumptions of a research approach to its research methods, in order to provide credible, accountable and legitimate answers to the research questions". According to Johnson and Christensen (2008), research design is the outline, plan or strategy that is going to be used to seek an answer to the research questions. It is a detailed plan aimed at explaining how a research study is to be conducted. Therefore, the research design adopted in this study is case study because it is qualitative research.

\section{Sample and sampling techniques}

Punch (2006:94) claims that sampling "is the process of selecting a few respondents from the population under study". Probability sampling techniques are defined as the methods that include random sampling, systematic sampling and improbability sampling selected for this study from the population of incarcerated prisoners enrolled in art education as an andragogy narrative for the purpose of rehabilitation (McColl, 2017). This study employed random sampling to select four secondary schools and purposive sampling to select two teachers from each school with a total of eight respondents that participated in this study. Creswell (2014) defines purposive sampling as a means through which participants are selected based on the given characteristics.

\section{Research instruments}

In the study, semi-structured interviews were used as the main data collection tool. According to Nieuwenhuis (2008), semi-structured interviews allow for in depth probing and extended responses; hence, the researchers have a set of predetermined questions on an interview schedule that guided the interview. An audiotape was used to record the interviews with permission from the participants. The utilisation of semi-structured interviews helped in refocusing the discussion so that accurate information gained from participants through rephrasing questions and observing non-verbal cues such as facial expressions.

\section{Data analysis}

A thematic analysis of data was used. Bricki and Green (2007) state that a thematic analysis is the record that looks across all the data in identifying the common issues that happen and identify the main themes that summarise all the views gathered. The teachers were interviewed and responded in English. The interviews were audio-recorded and concise field notes were additionally taken to ensure that the data was registered to authenticate the audio recording. The field notes also provided opportunities to record non-verbal communication, such as body language. The audio-recordings and field notes were reviewed several times in order to discover any deviances across the interviews.

\section{Thematic content analysis}

Thematic content analysis is a descriptive presentation of qualitative data. This analytic strategy is used to analyse classifications and present themes (patterns) that relate to the data. Thus, it is a process involving cutting across data in search of patterns and themes by giving all units of data a particular code (Ibrahim, 2012; Vaismoradi, Turunen \& Bondas, 2013). Thematic content analysis illustrates the data in detail and deals with diverse subjects 
via interpretations. It can be flexibly applied to enable surface (descriptive) and in-depth (interpretive) analysis as required (Vaismoradi et al., 2013). By so doing, this strategy gives the researcher an opportunity to understand the potential of any issue more widely; thus, allowing the researchers to determine precisely the relationships between concepts and compare them with the replicated data.

In recognition of its strengths, this data analysis technique was employed to cater for the qualitative data component in the current study. It was also employed in the analysis of documents. In this study, data from the interviews were transcribed within the shortest possible time after the interview sessions. Categories or themes established were assessed on how they converged or diverged on issues relating to the conception of teachers in transforming and improving teaching quality in secondary school education in South Africa.

\section{Results and findings}

Table 1: Distribution of selected teachers by gender, age, teaching experiences, academic and professional qualifications

\begin{tabular}{|c|l|l|c|l|l|}
\hline Respondents & Gender & $\begin{array}{c}\text { Age in } \\
\text { years }\end{array}$ & $\begin{array}{c}\text { Teaching } \\
\text { experience }\end{array}$ & $\begin{array}{c}\text { Highest } \\
\text { academic } \\
\text { qualification }\end{array}$ & $\begin{array}{c}\text { Highest professional } \\
\text { qualification }\end{array}$ \\
\hline CL1 & Male & 48 & 12 & BEd & Bachelor of Education \\
\hline CL2 & Male & 51 & 20 & BEd & Bachelor of Education \\
\hline CL3 & Female & 47 & 10 & MEd & Master of Education \\
\hline CL4 & Male & 44 & 17 & Honours & Honours in Education \\
\hline CL5 & Female & 53 & 21 & MEd & Master of Education \\
\hline CL6 & Male & 44 & 11 & Honours & Honours in Education \\
\hline CL7 & Male & 49 & 19 & BEd & Bachelor of Education \\
\hline CL8 & Female & 58 & 23 & Honours & Honours in Education \\
\hline
\end{tabular}

From Table 1, it is evident that all the teachers interviewed were holders of a degree at first degree, honours or master's level. The age of the teachers and years of teaching experience varied accordingly. Their academic qualifications made the participants confident in their teaching skills as they were at ease responding to questions that probed their conception on transforming and improving the teaching quality of education in secondary schools. All the selected teachers were professionally qualified. This assured the researcher of professional responses to the interview questions. Three out of the eight respondents were female.

The results are presented thematically under the two themes of "transformation strategies" and "teacher's role on transformation".

\section{THEME 1: Teachers' familiarity with transformation strategies}

Most school interviewees expressed their awareness to some teaching infrastructure such as ICT put in place by the government but some disclosed very limited familiarity with 
those infrastructures. This negatively affects teachers' conception, as there is still so much expectation on the teaching quality of education in secondary schools.

I am aware of some transformation infrastructure, for examples we have many computer in my school but the teacher are not given enough skills on how to use the infrastructure effectively for teaching. (CL2).

Three of the respondents were of the same opinion as highlighted in CL2's conversation; they all claimed that some of the infrastructures were very good in transforming and improving the teaching quality of education at all levels but required routine and consistent training that was not really put in place or appropriately planned to give the expected outcomes as required. The other respondent added that:

I have very little knowledge of the use some of the infrastructure and I am always looking forward for the opportunity to be trained on how to use it in teaching and learning but the stakeholders are only interested in its availability and not equipping us on how to use it successfully (CL5).

The third respondent in her own view was so funny and so serious about her disposition with regard the strategies and the teachers involved. She claimed that:

I have attended one or two workshop but sincerely my mind was not on what they were teaching us, I am interested in the allowance to be paid and other packages embedded, I also see the gathering as a place of meeting new friends for further social engagement (CL3).

It was indicative from the responses above that the teacher's conception about the transformation in quality of teaching is negative and it is not in any way transforming or improving the teaching quality of South African secondary school education as expected. Nevertheless, two other respondents' conception differed from the view of others concerning the contributions of infrastructure towards transformation of teaching quality in education:

Transformation when it comes to teaching and learning, as I observed I noticed that students rate of understanding increased when they enjoy being exposed to making use of some of these infrastructure in teaching (CL4).

In another view, similar to CL4's opinion, CL7 had the following to say:

Some of these transformation in teaching make students to be active and friendly during teaching and learning and improve the quality of teaching (CL7).

The opinion of the last two teachers was an indication of the awareness of government's effort in transforming and improving teaching quality in secondary school education in South Africa. They both see it in a positive direction and its importance on students' rate of learning and achievement as a whole.

\section{THEME 2: Teachers' familiarity with their roles in transformation}

In response to the question on the roles of the teacher on transforming and improving the teaching quality in secondary school education, the teachers narrated all their efforts in ensuring students' learning. It was observed that all the teachers were performing their normal obligations and duties but the response from the two indicated that they were not willing to have additional responsibilities of any form. In their opinion, they stated: 
I come to school regularly and ensure I perform my normal duties, I am not interested in any addition[al] responsibility that will not give me enough time to rest. My health is more important to me (CL6).

The other one was quoted as:

Transforming and improving the teaching quality in the school should be the responsibility of the government or school heads, once I go to class to teach as at when due, the rest is history (CL4).

These kind of responses indicate that some teachers are not willing or ready to have additional responsibilities in any form. This category of teachers has limited their responsibilities to a one-way method of teaching from time to time. Such a view assured the researchers of a lack of exposure to the relevant transformational ideas necessary to improve the teaching quality of education in secondary schools.

Furthermore, the remaining six teachers had a positive conception towards their roles in transforming and improving the teaching quality of secondary education. The majority of the teachers believed that it was important that the students' learning must be effective to bring improvement on the quality of teaching and education at all levels. They all had a similar opinion and submission towards their roles. Here is some of the information gathered by the researchers from the teachers:

Teaching is about transfer of knowledge, I am always willing to give my best towards transforming and improving the teaching quality of secondary school education system (CL8).

World is changing on daily basis, there is need for innovation for me as teacher in order to be relevant and impactful (CL1).

I am aware of my roles as teacher and always looking forward for additional role that will make my teaching effective (CL3).

\section{Conclusion}

The results generated from all the eight teachers used as respondents in this study show that their conceptions were mostly influenced by their beliefs (Eren, 2010). They see transformation as a task intended for improvement of teaching and learning and for accountability in schools. Based on this, scholars confirm that teachers possess strong beliefs that influence their conceptions (Calderhead, 2002). Furthermore, it is generally accepted in education that teachers' beliefs relate to their ways and manners of teaching (Gonzales \& Fuggan 2012; Good \& Brophy 2003; Dixon \& Haigh, 2008). Gipps and Brown (2005) assert that a better understanding of teachers' belief system or conceptual base significantly enhances educational effectiveness. Based on the evidence gleaned from the study, the researchers conclude that to understand transformation in teaching quality in secondary schools, the teachers need regular incentives, training and workshops because Susuwele-Banda (2005) argues that teachers' beliefs automatically influence their perceptions and judgements, which in turn affect their behaviours in the classroom. The understanding of teachers' roles and practices have strong implications on teaching and learning (Verdar, 2010) 


\section{Recommendations}

The aim of the study is to investigate conceptions of secondary schools teachers on understanding and improving the teaching quality. In the results, teachers have stated different opinions that can enhance transformation and improvement of teaching quality in secondary schools. Therefore, the following recommendation should be considered:

- The policy maker should increase the budget on secondary school education and monitor the process of implementation to achieve the desired goal.

- The government can also create a platform to encourage partnership for the funding of secondary school education.

- The government should motivate the teachers in secondary schools by providing special allowances, necessary incentives and other amenities that may enhance their teaching qualities.

- There should be regular effective training and workshops for the teachers in secondary schools to remind the teachers of their roles and responsibilities in teaching.

- The school authority should provide a conducive environment for teaching and learning in order to improve the morale of the teachers.

- The number of the students in the classroom should be adequate in order to avoid overcrowding.

\section{Implications for the study}

The study investigated the South African secondary school teachers' conceptions on transforming and improving teaching quality of education. The rate at which specific educational systems, especially in secondary schools, are no longer yielding the intended goals and objectives is the major concern of the researchers. The opinion of the researchers alone cannot form the data for the conclusion on this study. Hence, selected teachers were consulted to contribute their own insights into a subject matter from four different secondary schools in the Eastern Cape Province of South Africa. The research questions raised on the conception of teachers on transformation of teaching qualities was to find out whether the innovation influences teaching and learning and in one way or the other can improve teaching quality of education in secondary school. The results revealed that some of the teachers are already aware of the efforts of the government to improve the quality of secondary school education but the majority of them are not interested in understanding and implementing the new development. This implies that the effort that the government is putting in place may be futile if a proper check or monitoring is not put in place. Nevertheless, the conception of the teachers as perceived by many of them is influenced by their interest on their personal gain and additional allowances that can serve as motivating factor for them to perform wonderfully well.

The secondary school education is the bedrock that gives students an opportunity for better performance in a higher institution of learning. Therefore, the result of the study may serve as a knowledge base in the field of education of secondary school teachers' conception on the teaching quality of education. This would go a long way to find possible solutions to various problems militating against the quality of secondary school education in South Africa and beyond. The understanding of the knowledge on this study may increase the commitment of the stakeholders involved in the planning and implementation of secondary school education in South Africa. It was revealed by some of the teachers that they were 
not interested in some of the training because they expect some incentives that may serve as encouragement on their part. This can enable the teacher to have an idea on how to use some of the newly innovative skills that can assist in developing the teaching and learning process. Professional development must be put in place for the teachers from time to time. School-based programmes may be appropriate because it might gear toward teachers and school development and the outcome of the students' performance would likely be positive in most cases.

This study may also have implications on transforming and improving the teaching quality of South Africa secondary school education. The study shows the opinion of teachers and possible suggestions that can aid the quality of education ranging from introduction of incentives and allowances to a conducive teaching environment. Other researchers can also look at other factors generated by the teachers in this study.

\section{Ethical consideration}

Welman, Kruger and Mitchell (2005: 182) explain that ethical considerations and ethical behaviour are as important in research as they are in any other fields of human activity. As such, ethical considerations were included in the cover letter to inform the participants that participation was voluntary. Secondly, they had the right to withdraw at any time. Thirdly, they were also informed that there was no harm or risk in participating in the study, as it would not result in any physical or mental discomfort or any form of injury. They were also informed that their anonymity would be guaranteed, as their names would not be divulged in the coding of the interview result. This was further guaranteed by not requesting any personal information during the interview.

\section{References}

Bedi, K. \& Sharma, J.K. 2006. Benchmarking the quality of secondary education at the micro and policy imperatives. U21 Global working paper number 13/2006. Available at www. u21global.ed.sg. [Accessed 03 October 2009].

Bennel, P. \& Mukyanuzi, F. 2005. Is there teacher motivation crisis in Tanzania? A report commissioned by DFID.

Benson, J. 2005. A complete education?' Observation about the state of primary education in Tanzania. Hakielimu, working paper, 1, 2006.

Biggs, J. 2003. Teaching for quality learning at university, second edition: The Society for Research into Higher Education \& Open University Press. Edmunds: St Edmunds bury Press.

Boaduo N.A. 2005. Secondary education provision in Africa: What form should it take in the twenty-first century? New York: Research Gate.

Bricki, N., \& Green, J. 2007. A guide to using qualitative research methodology. Medecins Sans Frontieres, (pp 11-13). Buckingham: Open University Press.

Calderhead, J. 2002. Teachers: beliefs and knowledge. In D. Berliner \& R. Calfree (Eds.). Handbook of educational psychology, (pp. 709-725). New York: Macmillan.

Chapman, D. W. \& Austin, A. E. 2002. Higher Education in the Developing World: Changing Contexts and Institutional Responses. London: Greenwood Press. 
Creswell, J.W. 2014. Research design: Quantitative and qualitative mixed methods approaches, 4th ed. Thousand Oaks, CA: Sage.

Davidson, E. 2006. The pivotal role of teacher motivation in Tanzania. Dar es salam: Hakielimu. Working paper 7 .

Department of Education. 2013. Inclusive education comes under spotlight at portfolio committee on basic education. Pretoria: Government Printers.

Dixon, H. \& Haigh, M. 2008. Changing mathematics teachers' conceptions of assessment and feedback. Teacher Development, (13)2, 173-186.

Eckel, P., Hill, B. \& Green, M. 2002. On change, En route to transformation. Washington, DC: American Council on Education.

Eren, A. 2010. Consonance and dissonance between Turkish prospective teachers' values and practices: Conceptions about teaching, learning and assessment. Australian Journal of Teacher Education, (35)3.

Gelo, O., Braakmann, D. K., \& Benetka, G. 2008. Quantitative and qualitative research: Beyond the debate. Integrated Psychological Behavior, 42, 266-290. https://doi.org/10.1007/ s12124-008-9078-3

Gipps, C., Brown, M., McCallum, B and McAlister, S., 2005. Intuition or evidence? Teachers and national assessment of seven-year-olds. Buckingham, UK: Open University Press.

Gonzales R., \& Fuggan C. G. 2012. Exploring the Conceptual and Psychometric Properties of Classroom Assessment. The International Journal of Educational and Psychological Assessment. (9) 2.

Good, T. L. \& Brophy, J. E. 2003. Looking in classrooms, 9th ed. Boston: Allyn and Bacon.

Hakielimu E. 2007. Redefine quality education in Tanzania. From input to capabilities. Working paper, October, 2007. Dar es Salaam.

Hanushek, E. A. \& Woessman, L. 2007. The role of school improvement in economic development. National Bureau of Economic Research Working Paper (12832).

Ibrahim, A. M. 2012. Thematic analysis: A critical review of its process and evaluation. WEI International European Academic Conference Proceedings 6(3), 1-14.

Isaacs, S. 2007. Survey of ICT and education in Africa: South Africa Country Report South Africa - 1. www.infodev.org [Accessed: 17 March 2017].

Johnson, B. \& Christensen, L. 2008. Educational research: Quantitative, qualitative, and mixed approaches, 3rd ed. Thousand Oaks, CA: Sage.

Komba, W. \& Nkumbi, E. 2008. Impediments towards enhancing the pedagogical content knowledge to secondary school teachers in Tanzania. Journal of International Cooperation in Education, 11(3), 67-83.

Lomas, L. 2002. Does the Development of Mass Education Necessary Mean the end of Quality? Quality in Higher Education, 8(1), 71-79. https://doi.org/10.1080/13538320220127461

Lomas, L. 2007. Zen, motorcycle maintenance and quality in higher education. Quality Assurance in Education, 15(4), 402-412. https://doi.org/10.1108/09684880710829974 
Makombe, I. A. M., Kihombo, A. R., Sesabo, J. B., Hodgson, A. \& Spours, K. 2010. Building partnership for poverty reduction in Tanzania: Improving successful completion and progression from secondary education into further studies and working life.

Morogoro: Mzumbe University. A research report presented at a dissemination seminar, Morogoro, November, 2010.

Manyanga, T. 2007. Standards for quality in tertiary education: The case of Tanzania. Quality Assurance in Education, 16(2), 164-180. https://doi.org/10.1108/09684880810868448

McColls, J.H. 2017. Statistics glossary. New York: McGrawhill.

Mosha, H.J. 2000. Conceptualizing quality education. New York: McGrawhill.

Murnane, R., Willett, J., Braatz, M. \& Duhaldeborde, Y. 2001. Do different dimensions of male high school students' skills predict labor market success a decade later? Evidence from the NLSY. Economics of Education Review, 20(4), 311-320. https://doi.org/10.1016/ S0272-7757(00)00056-X

Nieuwenhius, J. 2008. Qualitative research designs and data gathering techniques. In K. Maree (Ed). First steps in research. Pretoria: Van Schaik

Olaitan, S.O. \& Agusiobo, N.O. 2001. Principles of practice teaching. New York.

Ololube N.P. 2005. School effectiveness and quality improvement: quality teaching in Nigerian secondary schools. The African Symposium: An On Line Journal of African Educational Research Network, 5(4), 17-31.

Parri, J. 2006. Quality in higher education. Vadyba/management.m.Nr.2 (11).

Punch, K.F. 2006. Introduction to qualitative and quantitative research approaches.

London: Sage.

Shahzad, S. 2007. A study to investigate the quality of education at intermediate level in Punjab. Doctoral thesis. Rawalpindi, Pakistan: University of Arid Agriculture.

Sumra, S. \& Rajani, R. 2006. Secondary education in Tanzania: Key policy challenges.

Working paper on The Norwegian Post-Primary Education Fund for East Africa (NPEF),

Oslo, and 13-14 Sept, 2006.

Susuwele-Banda W. J. 2005. Classroom assessment in Malawi: Teachers' perceptions and practices in mathematics. PhD thesis, Blacksburg, Virginia.

Terre Blanche, M, Durrheim, K. \& Painter, D. 2006. Research in practice: Applied methods for the social sciences, 2nd edition. Cape Town: UCT Press.

Vaismoradi, M., Turunen, H. \& Bondas, T. 2013. Content analysis and thematic analysis: Implications for conducting qualitative descriptive study. Journal of Nursing \& Health Sciences 15(3), 398-405. https://doi.org/10.1111/nhs.12048

Vavrus, F. 2009. The cultural politics of constructivist pedagogies: Teacher education reform in the United Republic of Tanzania. International Journal of Education Development, 29, 303311. https://doi.org/10.1016/j.ijedudev.2008.05.002

Verdar, E. 2010. Sixth, seventh and eighth grade teachers' conception of assessment. MSc. thesis. Graduate School of Social Sciences of Middle East Technical University 
Wedgwood, R. 2007. Education and poverty reduction in Tanzania. International Journal of Educational Development, 27(4), 383-396. https://doi.org/10.1016/j.ijedudev.2006.10.005

Welman, J.C, Kruger, S.J \& Mitchell, B. 2005. Research methodology, (3rd ed. Cape Town: Oxford University Press. 